\title{
Effect of Substrate Temperatures on the Structural and Optical Properties of Na-Doped ZnO Thin Films
}

\author{
Suha A. Najim \\ Department of Physics/ College of Science/ University of Mosul
}

(Received 20/1/2014; Accepted 5/5/2014)

\begin{abstract}
$\mathrm{ZnO}$ thin films doped with $\mathrm{Na}$ have been prepared by chemical vapor deposition technique on the glass substrate at different temperatures $\left(400,450,500{ }^{\circ} \mathrm{C}\right)$ for $20 \mathrm{~min}$. By increasing the dopant $\mathrm{Na}$ from 0 to $20 \%$ in $\mathrm{ZnO}$ thin films were found to lead to pronounced changes in their structure. From optical properties the band gap energy of the Na-doped $\mathrm{ZnO}$ thin films is affected by increasing substrate temperatures and $\mathrm{Na}$ doping. X-ray diffraction (XRD) has shown that the maximum intensity peak corresponds to the (002) predominant orientation for $\mathrm{ZnO}$ films. Scanning Electron Microscope (SEM) images reveal the formation of Na-doped $\mathrm{ZnO}$ films having better crystalline behavior by increasing the substrate temperature at $500^{\circ} \mathrm{C}$. Energy dispersive X-ray analysis (EDXA) shows that the structure of $\mathrm{ZnO}$ contains $\mathrm{Zn}$ and $\mathrm{O}$ elements for undoped and $\mathrm{Na}$ for doping state.
\end{abstract}

Keywords: $\mathrm{ZnO}$ thin film, $\mathrm{ZnO}-\mathrm{Na}$ doped, transparent conducting oxides

Na تأثثير درجات حرارة الأرضية على الخواص التركيبية والبصرية لأغشية

\begin{abstract}
الملخص
حضرت أغشية ZnO الرقيقة المطعمة بالصوديوم (Na) بواسطة تقنية ترسيب البخار الكيميائي chemical vapor deposition (CVD) التطعيم من Na (20\%) في أغشية ZnO الرقيقة وجد حصول تغييرات واضحة في التركيب البلوري. من الخواص البصرية

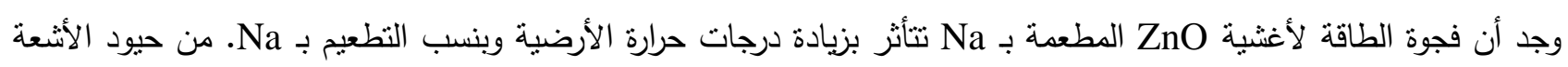

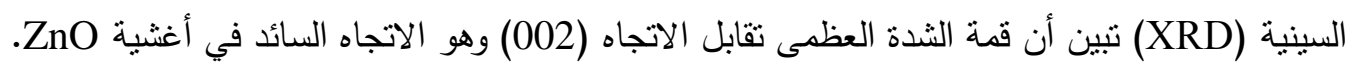

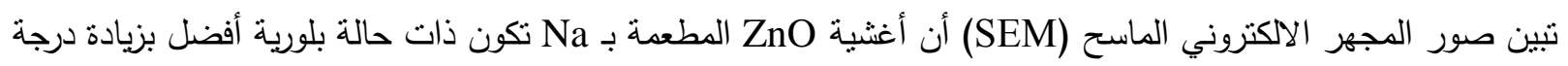

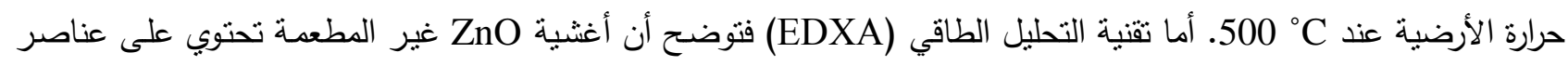

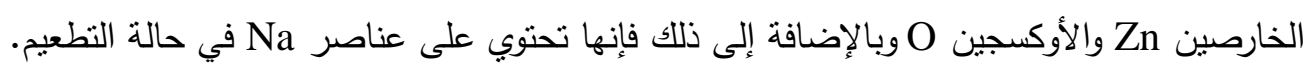

\section{INTRODUCTION}

Zinc oxide is a II-VI group compound semiconductor with a wide band gap. Recently, $\mathrm{ZnO}$ has been of great interest because of its direct band gap of (3.37) $\mathrm{eV}$ and relatively high exciton binding energy $(60 \mathrm{meV})$ at room temperature. $\mathrm{ZnO}$ is used in many applications such as solar cells (Lee et al., 2007), laser devices (Lee et al., 1996), gas sensor devices (DeVoe, 2001) and short wavelength light emitting diodes (Tsukazaki et al., 2005). The main purpose for doping $\mathrm{ZnO}$ in general is to modify its electrical and optoelectronic properties (Briscoe et al., 2009). Various dopants are known to enhance the structural and optical properties of $\mathrm{ZnO}$ thin films (Chen et al., 2010) (Henley et al., 2004). However, less attention has been paid to Na doping in ZnO. The doping 
of $\mathrm{Na}$ in $\mathrm{ZnO}$ is expected to modify the structure, surface morphology, luminescent and other physical or chemical properties of $\mathrm{ZnO}$ (Wang and Gao, 2009) (Karthikeyan et al., 2009).

Less commonly, in situ doping can also affect $\mathrm{ZnO}$ growth and structure. To date, many growth techniques, such as pulsed laser deposition (PLD) (Zhao et al., 2009), molecular beam epitaxy (MBE) (Chen et al., 1998), spray pyrolysis (Ma and Lee, 2000), metal organic chemicalvapor deposition (MOCVD) (Sun et al., 2008) and Rf magnetron sputtering (Song et al., 2002) have been widely applied to prepare high quality $\mathrm{ZnO}$ films. Among these techniques, the chemical vapor deposition (CVD) method is popular due to its simplicity, safety and low cost (Purica et al., 2002).

The properties of $\mathrm{ZnO}$ films depend on various parameters such as deposition rate, substrate temperature, pressure and annealing temperature (Mohsen et al., 2012). One of the most important factors in preparing $\mathrm{ZnO}$ film by CVD is the substrate temperature.

In this paper, $\mathrm{ZnO}$ thin films of $\mathrm{Na}$-doped were prepared by CVD method. The aim of this work is to study the influence of different substrate temperatures and $\mathrm{Na}$ doping on the structures and optical properties using by XRD, SEM,EDXA and transmittance spectra.

\section{EXPERIMENTAL}

$\mathrm{ZnO}$ and $\mathrm{ZnO}: \mathrm{Na}$ thin films were deposited on the cleaned glass substrate by chemical vapor deposition with different substrate temperatures $\left(400,450,500{ }^{\circ} \mathrm{C}\right)$ for $20 \mathrm{~min}$. High purity $(99.99 \%)$ zinc acetate powder $\left(\mathrm{Zn}\left(\mathrm{CH}_{3} \mathrm{COO}\right)_{2} .2 \mathrm{H}_{2} \mathrm{O}\right)$ was used as a source as CVD in our method.

Glass substrates were first rinsed in ethanol for $5 \mathrm{~min}$. The substrates were then rinsed thoroughly in distilled water and dried in acetone just before they were loaded into the system for film deposition.

The temperature was controlled by an electronic temperature controller. Air flow through the experiment was about $0.5 \mathrm{~L} / \mathrm{min}$. Deposition time was kept constant at (10 minutes) for both the pure and doped samples.

The thickness of films was measured by the gravimetric method and it was around $1 \mu \mathrm{m}$. Then, the same explained method was used for the preparation of $\mathrm{ZnO}: \mathrm{Na}$ thin film with various $\mathrm{Na}$ concentrations $(0,10,20) \%$ at substrate temperatures $\left(400,450,500{ }^{\circ} \mathrm{C}\right)$.

The structure of the films was determined by X-ray diffraction measurements with $40 \mathrm{kV}, 20$ $\mathrm{mA}$ (XRD, Bruker/D8-advance with CuK $\alpha$ radiation $(\lambda=1.54178 \AA$ ), Germany), in the scan range of $2 \theta$ between $20^{\circ}-80^{\circ}$. The surface morphology of the $\mathrm{ZnO}$ films was investigated by scanning electron microscopy (SEM) (FESEM, HITACHI S7900, Japan). Then the films were characterized by using the energy dispersive X-ray analysis (EDXA, HORIBA EMAX Energy EX-950, Japan) (in Sumy state university/ Ukraine).

The transmittance of the $\mathrm{ZnO}$ and $\mathrm{ZnO}: \mathrm{Na}$ thin films was measured using a spectrophotometer in the range (320-1000 nm). Then the energy band gap of both $\mathrm{ZnO}$ and $\mathrm{ZnO}: \mathrm{Na}$ films at three different substrate temperatures through the absorption spectra was calculated.

\section{Structural properties \\ 1- X-ray diffraction:}

\section{RESULTS AND DISCUSSION}

The X-ray diffraction pattern of pure and $\mathrm{Na}$-doped $\mathrm{ZnO}(\mathrm{Na}=10 \%$ and $20 \%)$ films deposited at different substrate temperatures $\left(400,450,500{ }^{\circ} \mathrm{C}\right)$ with a preferred orientation of $(002)$ is shown in Fig.(1a-c). The presence of diffraction peaks indicates the polycrystalline nature of the films with hexagonal (wurtzite) structure.

The X-ray diffraction peaks appearing at $2 \theta=31.82^{\circ}, 34.48^{\circ}, 36.26,47.62^{\circ}, 56.63^{\circ}, 62.88^{\circ}$ are due to (100), (002), (101), (102), (110), (103) planes respectively, were observed that for pure sample at $400{ }^{\circ} \mathrm{C}$. The data are in agreement with the Joint Committee on Powder Diffraction Standards (JCPDS) card for $\mathrm{ZnO}$ (Frank, 1976). 
Fig.(1a) showed that there is no change in the intensity of all orientations $(100,002,101,102$, 110, 103). However, we can see in these Fig. (1a-c) the appearance of other peak may represent the plane (004) at $2 \theta=72.5$ when the $\mathrm{ZnO}$ doped with $10 \%$ and $20 \% \mathrm{Na}$ and peak at $2 \theta=25$ may be due to pure $\mathrm{Na}$ (Mariappan et al., 2014). But for the $\mathrm{ZnO}$ films obtained at $450{ }^{\circ} \mathrm{C}$, It is clear that the intensity of (002) increased in comparison with the films at $400{ }^{\circ} \mathrm{C}$ for pure and doped $(10 \%$ and $20 \%$ ). The increase in preferential orientation is attributed with the increased number of grains along the plane. From other side, the peak intensities of $(100,101,102,103$ and 004) for pure and doped $20 \%$ appeared to be smaller in Fig.(1b). For the film deposited at $500{ }^{\circ} \mathrm{C}$, the peak intensities of $(100,101$ and 102) and $\mathrm{Na}$ peak are increased by increasing substrate temperature and Na doping in comparison with $400{ }^{\circ} \mathrm{C}$ and $450{ }^{\circ} \mathrm{C}$, Fig.(1c).
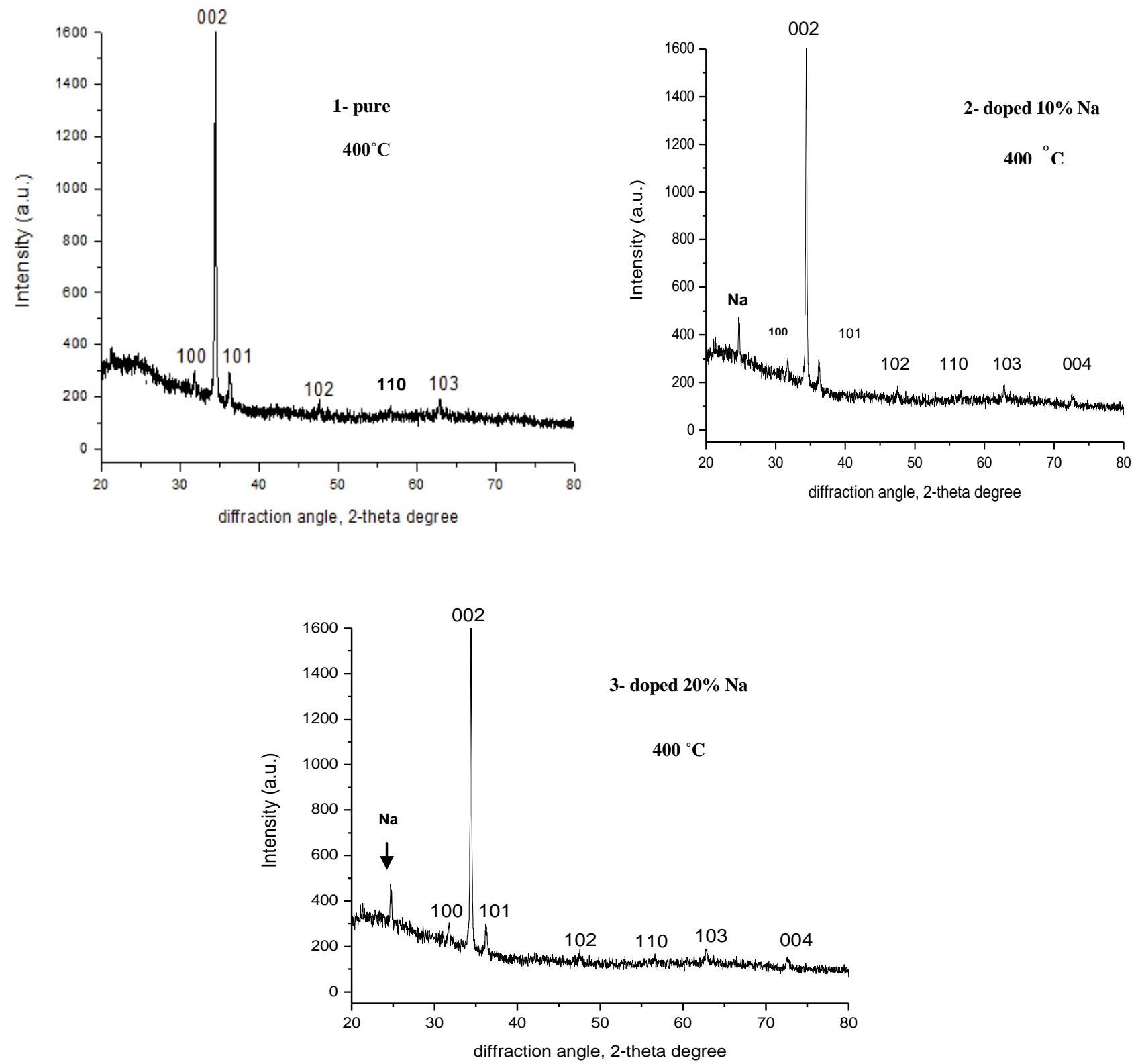

Fig. 1a: XRD pattern of $\mathrm{ZnO}$ films of (1-pure) andP doped $(10 \%, 20 \%)$ Na at $400{ }^{\circ} \mathrm{C}$. 

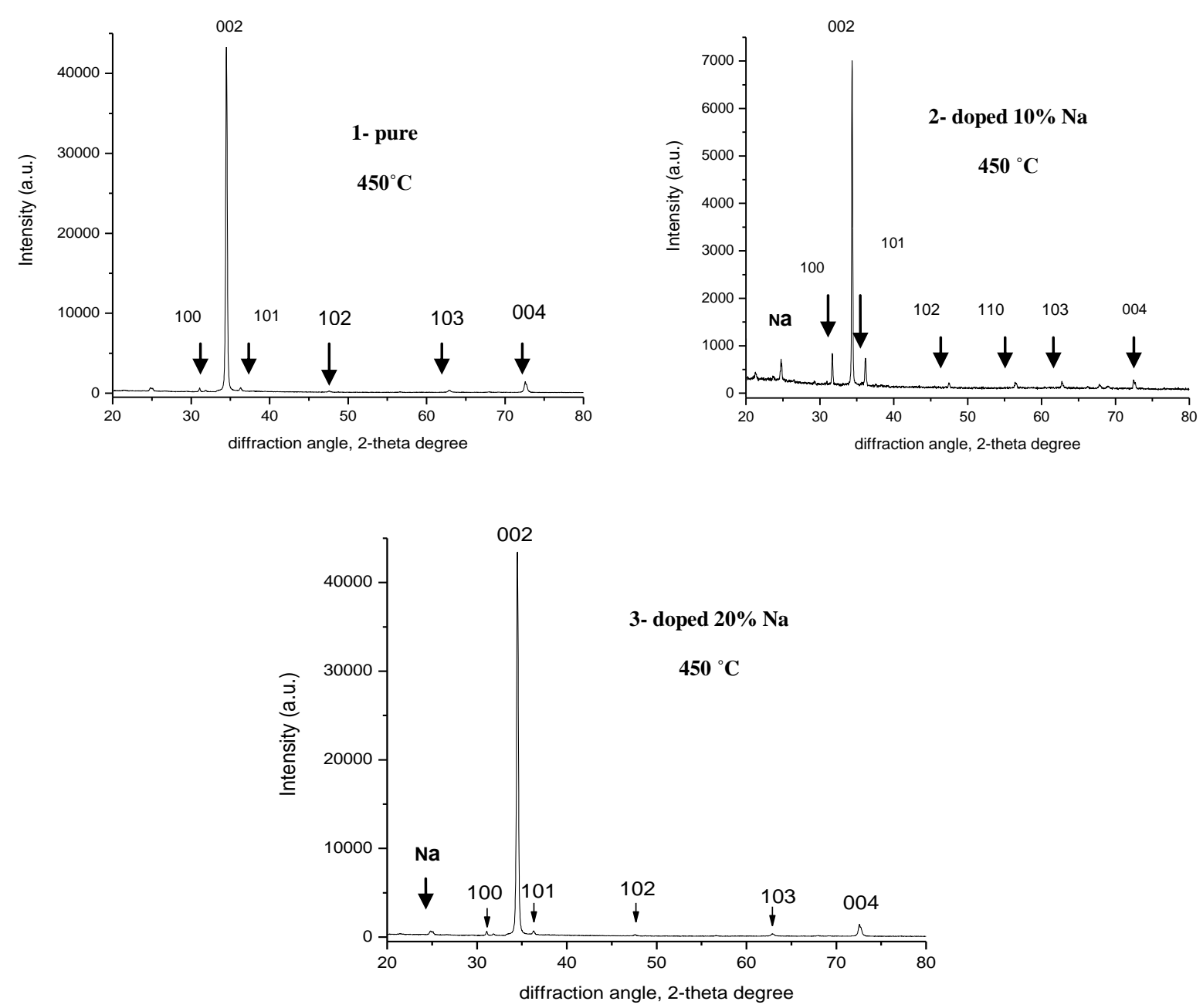

Fig.1b: XRD pattern of $\mathrm{ZnO}$ films of (1-pure) and doped $(10 \%, 20 \%) \mathrm{Na}$ at $450{ }^{\circ} \mathrm{C}$.
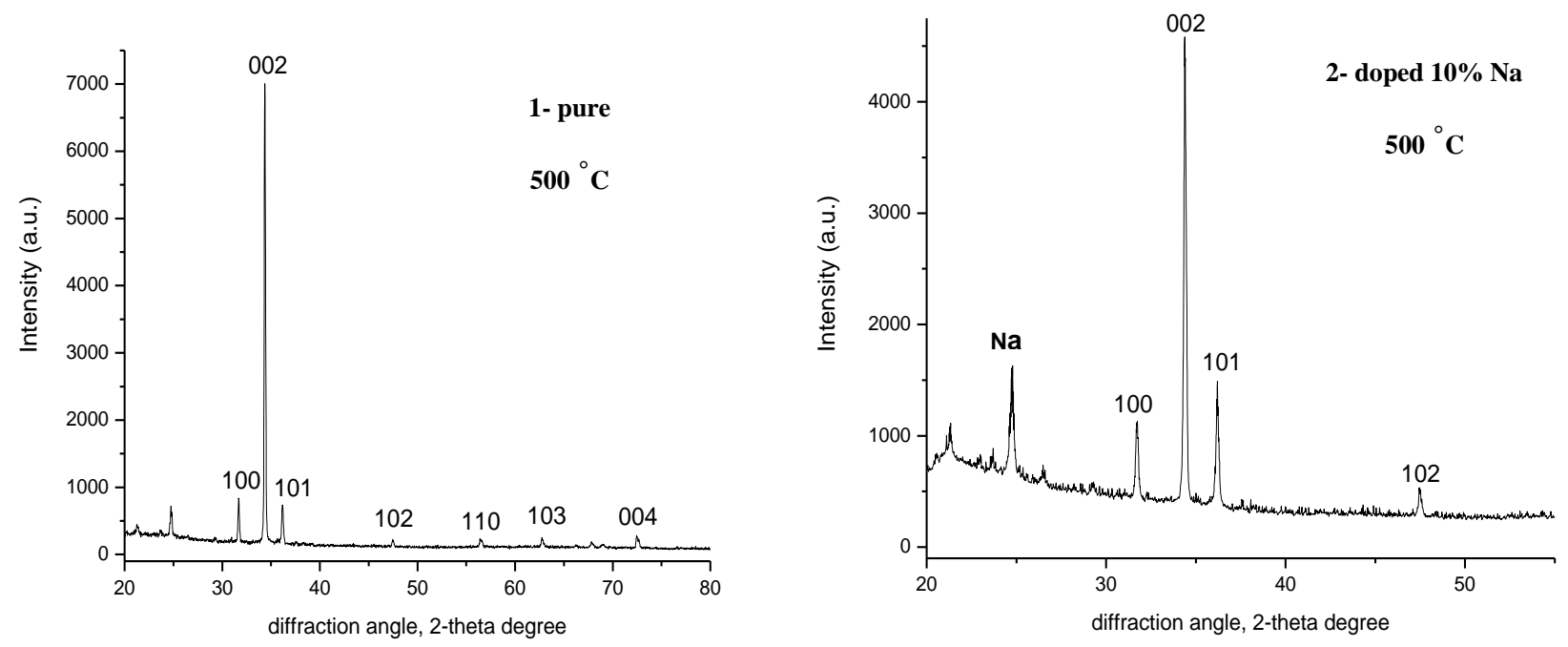


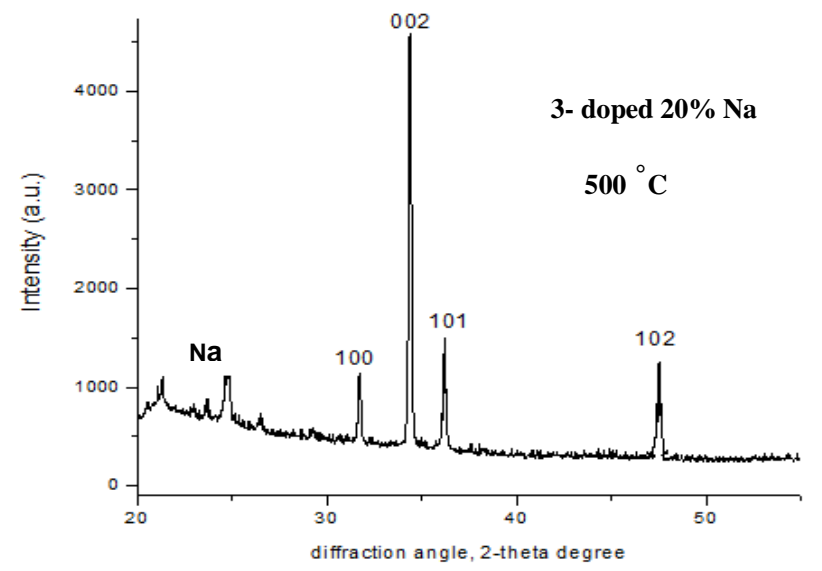

Fig. 1c: XRD pattern of $\mathrm{ZnO}$ films of (1-pure) \&doped $(10 \%, 20 \%)$ Na at $500{ }^{\circ} \mathrm{C}$.

\section{2- Scanning electron microscopy:}

Scanning electron microscopy (SEM) was used for the study of surface morphological changes of pure and doped $\mathrm{ZnO}$ films prepared at different temperatures. Fig. (2a-c) shows the SEM images of pure and $\mathrm{Na}$-doped $\mathrm{ZnO}$ films deposited at substrate temperatures $400,450,500^{\circ} \mathrm{C}$.

The surface morphology of the films is strongly dependent on the substrate temperature. High temperature favors rapid and defect free growth of crystallites due to oxidation of $\mathrm{Zn}$ atoms and optimum surface of diffusion of the species, whereas a low temperature results in the growth of disordered poorly crystallized structure. The development of a smooth, dense and uniform microstructural with good adhesion to the substrate is observed with the increase of substrate temperature (Mariappan et al., 2014).

Fig. 2a shows the surface morphology formed with non-uniform distribution of the grains with agglomeration small crystallites in the case of $\mathrm{Na}$ - doped $(20 \%)$ formed at $400{ }^{\circ} \mathrm{C}$. The film deposited at $450{ }^{\circ} \mathrm{C}$ (Fig.2b) has slightly improvement in crystallinity from Fig. 2a. In Fig.2c the images indicate to better crystalline behavior and the grains are densely packed, having different sizes and figures.
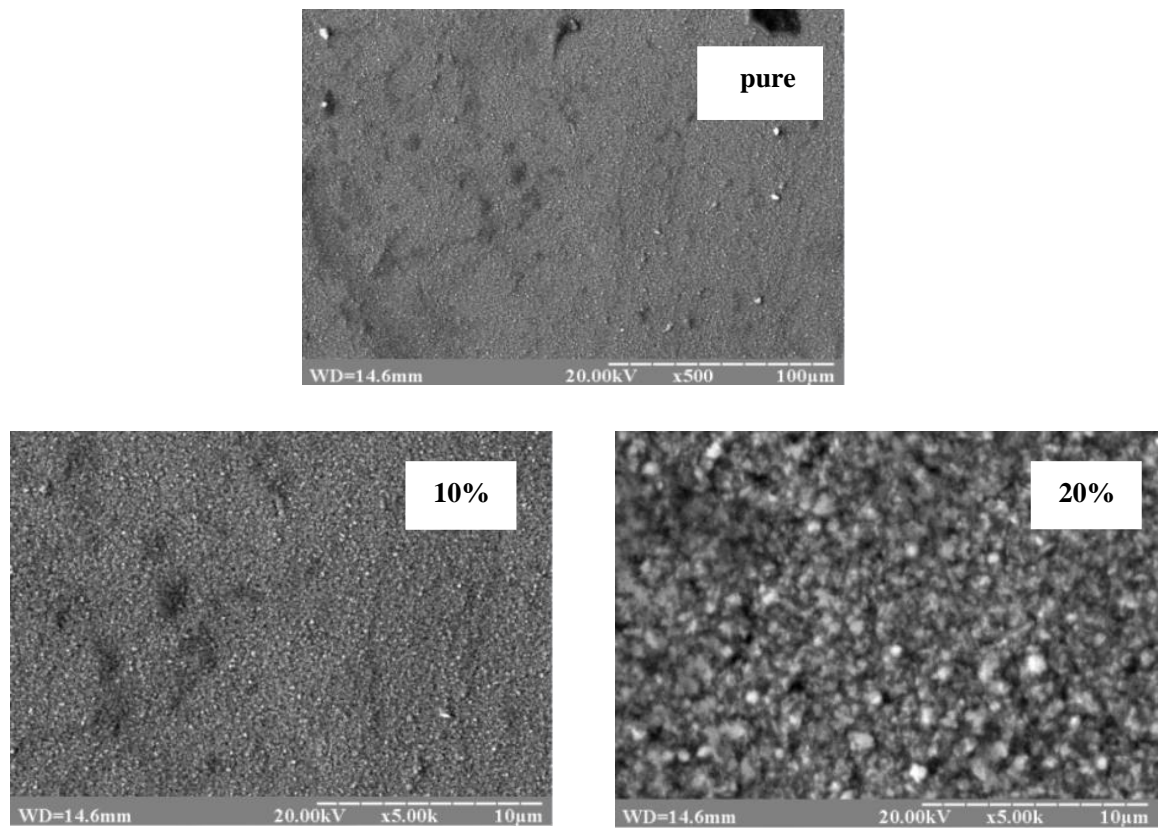

Fig. 2a: SEM of thin $\mathrm{ZnO}$ pure and doped with $(10 \%$ \& $20 \%) \mathrm{Na}$ at $400{ }^{\circ} \mathrm{C}$. 

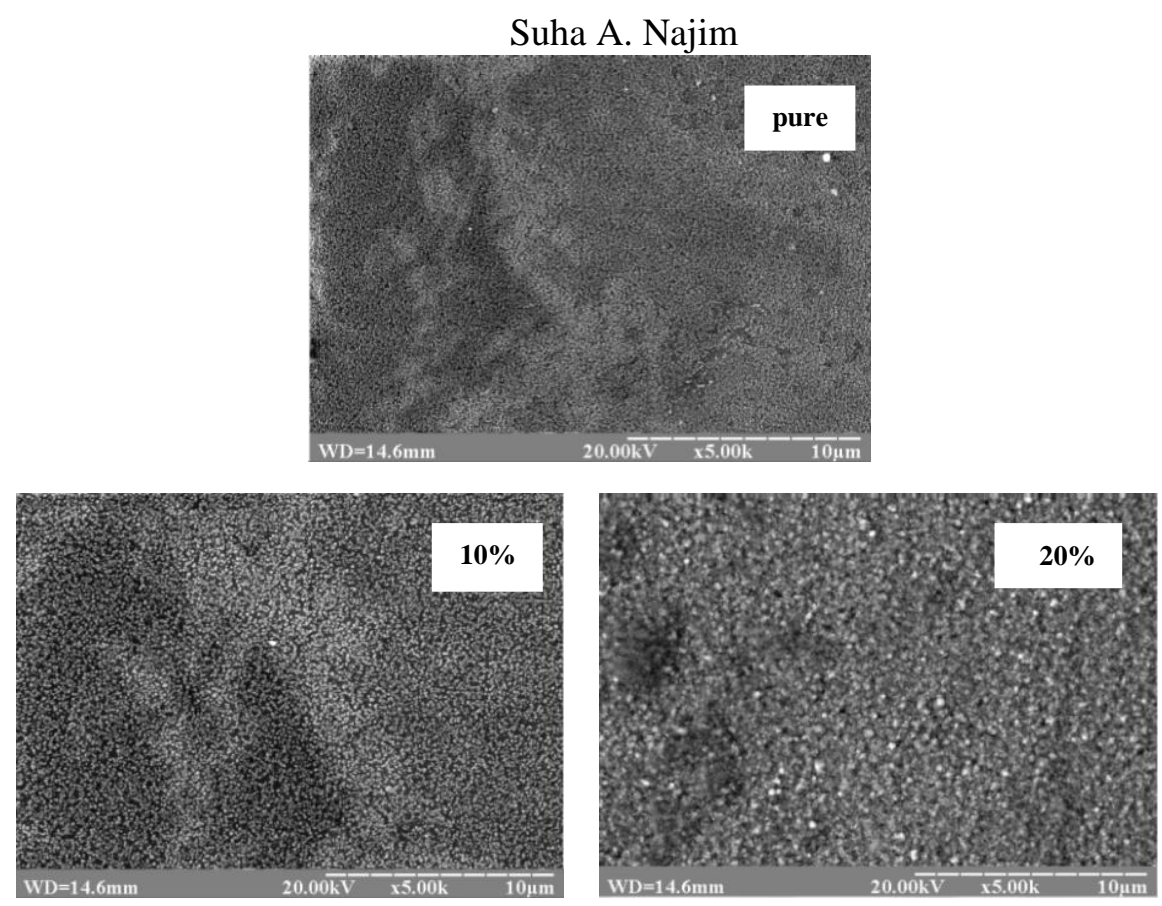

Fig. 2b: SEM of thin $\mathrm{ZnO}$ pure and doped with $(10 \% \& 20 \%) \mathrm{Na}$ at $450{ }^{\circ} \mathrm{C}$.
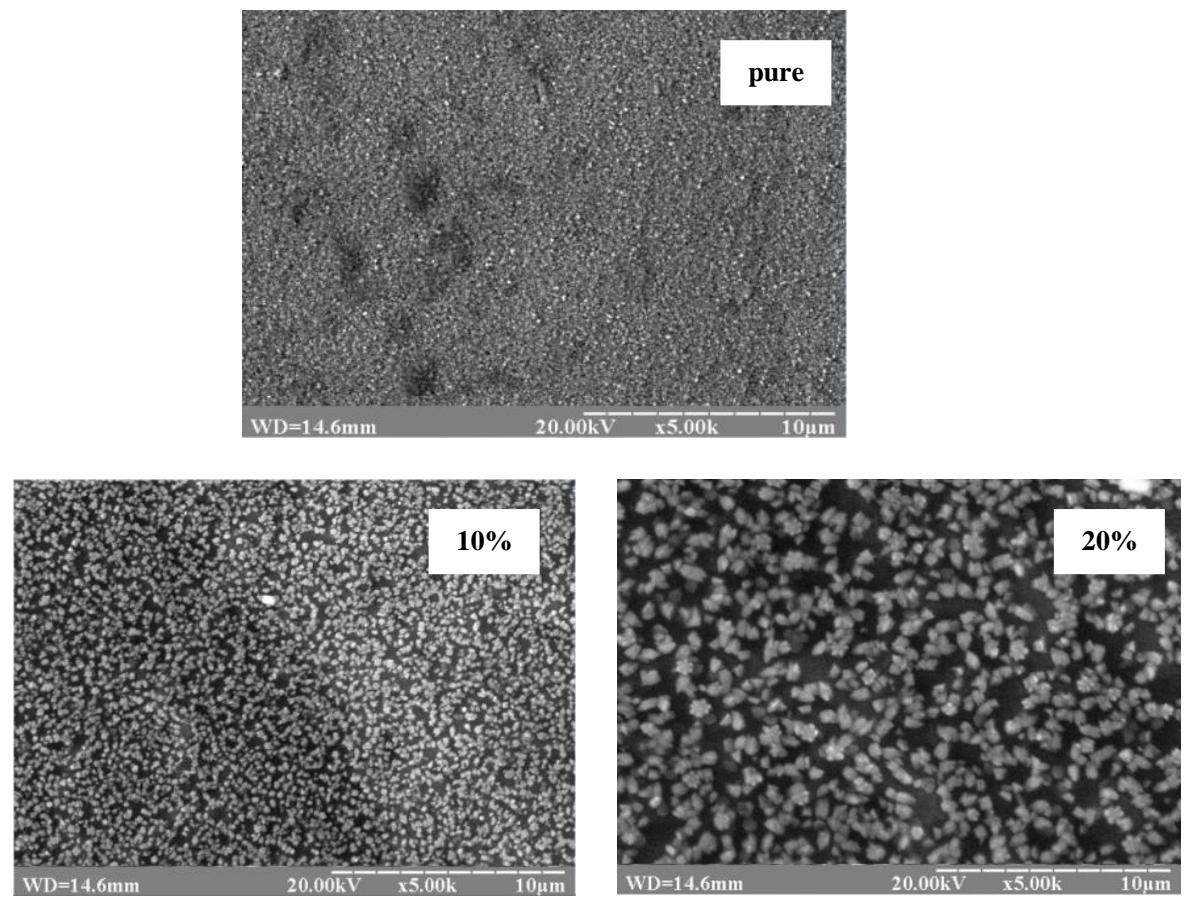

Fig. 2c: SEM of thin $\mathrm{ZnO}$ pure and doped with $(10 \% \& 20 \%) \mathrm{Na}$ at $500{ }^{\circ} \mathrm{C}$.

\section{3- EDXA analysis:}

EDXA analysis for $\mathrm{ZnO}$ pure and doped thin films as shown in Figs.(3 a,b) respectively shows that the dominant composition of $\mathrm{ZnO}$ and the details of the relative analysis are depicted in (Table 1). Whereas the quantitative analysis of the as-deposited $\mathrm{ZnO}$ films shows two strong peaks corresponding to $\mathrm{Zn}$ and $\mathrm{O}$ elements, which refers the high purity of the $\mathrm{ZnO}$ thin films. However, in the doping state we observed the appearance of $\mathrm{Na}$ element with high intensity due to high concentration $(20 \% \mathrm{Na})$ as well as two strong peaks corresponding to $\mathrm{Zn}$ element and another peak due to $\mathrm{O}$ element. 


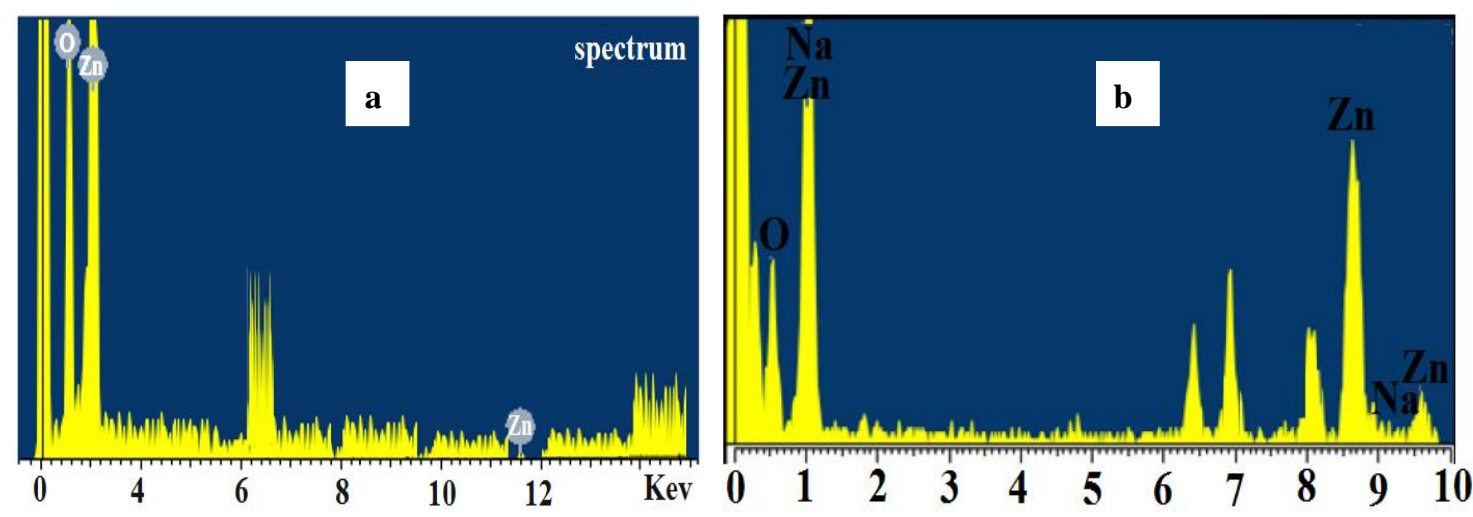

Fig. 3: EDXA of $\mathrm{ZnO}$ thin films a- pure, b- doped $20 \% \mathrm{Na}$

Table 1: Elemental analysis of $\mathrm{ZnO}$ doped at $20 \% \mathrm{Na}$

\begin{tabular}{|c|c|c|}
\hline ELEMENT & WEIGHT \% & ATOMIC \% \\
\hline $\mathrm{O}$ & 25.80 & 57.48 \\
\hline $\mathrm{Zn}$ & 71.45 & 39.03 \\
\hline $\mathrm{Na}$ & 2.75 & 2.49 \\
\hline
\end{tabular}

\section{Optical Properties:}

\section{1- Optical transmittance:}

Figure (4a-c) shows the optical transmittance spectra of Na-doped thin films in the wavelength range between 320 to $1000 \mathrm{~nm}$. It is observed that the transmittance has a tendency to increase with $\mathrm{Na}$ content. The highest transmittance edge was recorded at $62 \%$ for a sample with $20 \% \mathrm{Na}$ while the lowest transmittance edge was obtained for $0 \% \mathrm{Na}$ sample at $43 \%$, over the same wavelength (400nm). An increment in the transmittance percentage is due to the progression of $\mathrm{Na}$ in the thin film that enlarges the particle size and it slightly contributes to this phenomenon. The variation of thickness $(\mathrm{d} \mu \mathrm{m})$ with $\mathrm{Na}$ concentration at different substrate temps. is shown in (Table 2).
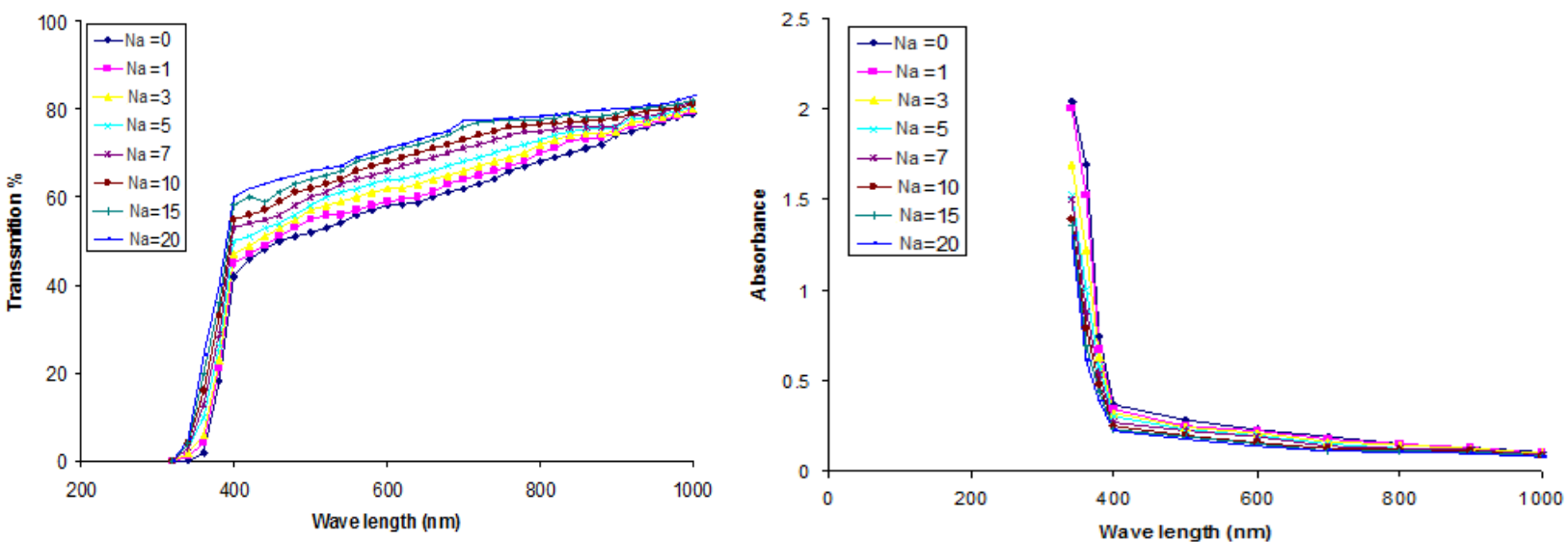

Fig. 4a: Transmittance \& Absorbance spectra of $\mathrm{ZnO}$ : Na films at $400{ }^{\circ} \mathrm{C}$. 

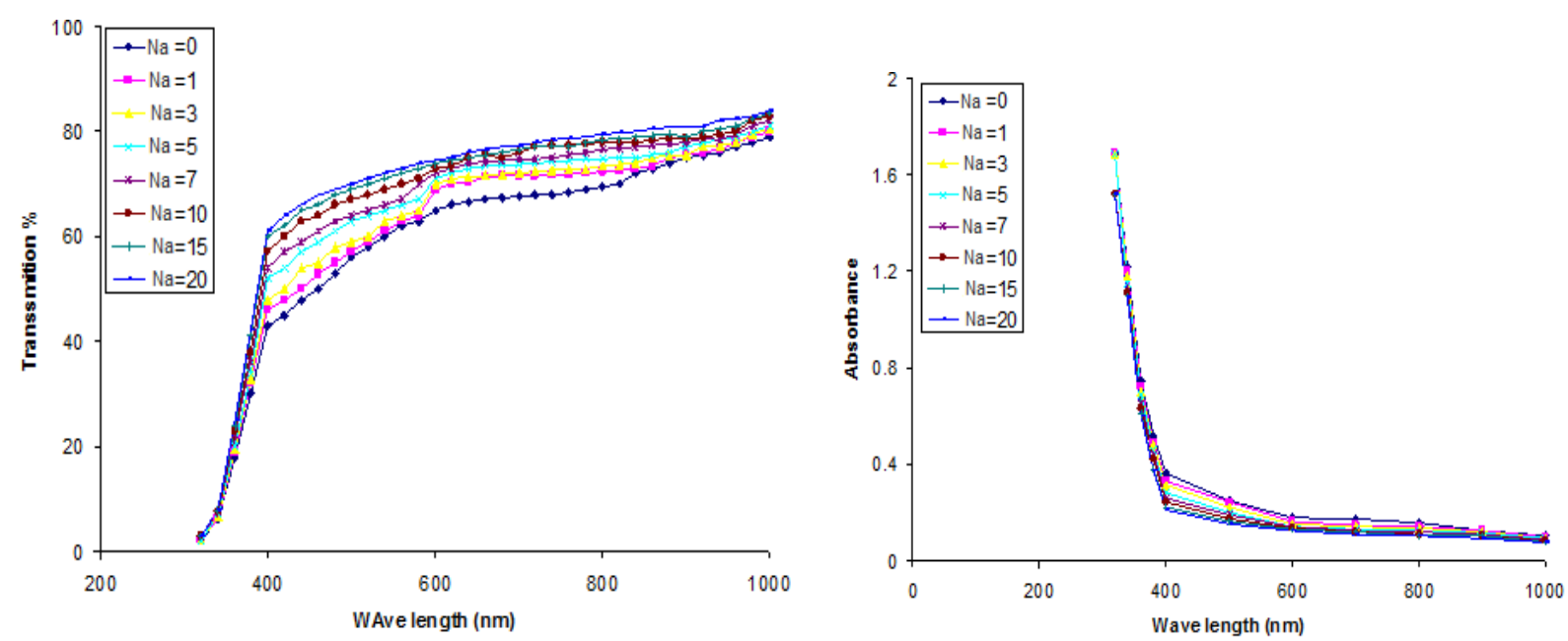

Fig. 4b: Transmittance \& Absorbance spectra of $\mathrm{ZnO}$ : Na films at $450{ }^{\circ} \mathrm{C}$.
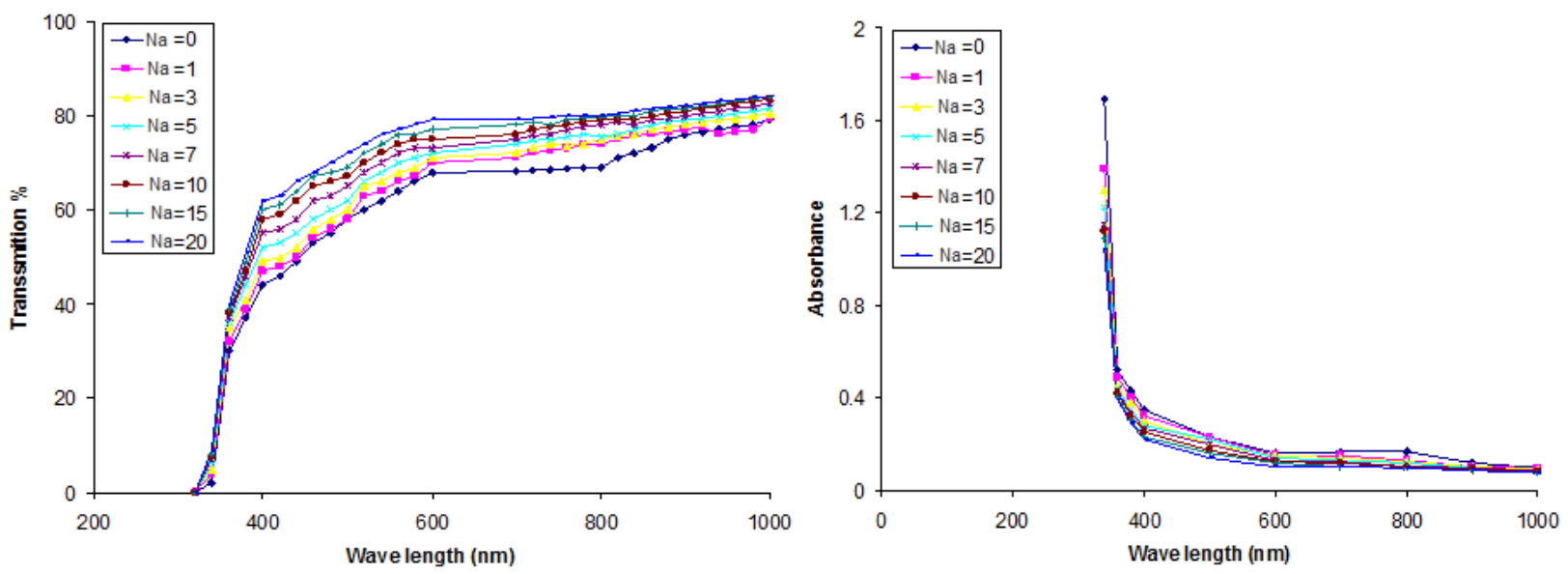

Fig. 4c: Transmittance and Absorbance spectra of $\mathrm{ZnO}$ : Na films at $500{ }^{\circ} \mathrm{C}$.

Table 2: Variation of thickness $(\mathrm{d} \mu \mathrm{m})$ with Na percentage at different substrate temps. (400, $\left.450,500{ }^{\circ} \mathrm{C}\right)$

\begin{tabular}{|c|c|c|c|}
\hline \multirow{2}{*}{$\mathbf{N a} \%$} & $\mathbf{T = 4 0 0}{ }^{\circ} \mathbf{C}$ & $\mathbf{T}(\boldsymbol{\mu} \mathbf{4 5 0})$ & $\mathbf{T}$ \\
\cline { 2 - 4 } & 0.95 & 1.01 & $\mathbf{T}=\mathbf{5 0 0}{ }^{\circ} \mathbf{C}$ \\
\hline $0 \%$ & 0.954 & 0.97 & 0.97 \\
\hline $1 \%$ & 1.05 & 1.05 & 1.05 \\
\hline $3 \%$ & 0.99 & 0.99 & 0.99 \\
\hline $5 \%$ & 0.103 & 1.05 & 1.01 \\
\hline $7 \%$ & 0.97 & 0.99 & 0.99 \\
\hline $10 \%$ & 0.99 & 1.02 & 1.03 \\
\hline $15 \%$ & 1.05 & 1.05 & 1.05 \\
\hline $20 \%$ & & & \\
\hline
\end{tabular}

\section{2- Optical absorption:}

The relation between absorption coefficient $(\alpha)$ and photon energy for direct transitions is given by [Azimirad et al., 2006].

$\alpha \mathrm{h} v=\mathrm{A}(\mathrm{h} v-\mathrm{Eg})^{1 / 2}$

where, $\mathrm{h}$ is the Plank constant, $v$ is the frequency of the incident photon, $\mathrm{A}$ is a constant depending on the electron-hole mobility and $\mathrm{E}_{\mathrm{g}}$ is the optical band gap energy. The plots of $(\alpha \mathrm{h} v)^{2}$ versus $\mathrm{h} v$ 
will have a linear region and extrapolation of the straight line to zero absorption gives the energy gap for different substrate temperatures and Na concentrations, are shown in Fig.5.

For pure $\mathrm{ZnO}$ thin film, the optical band gap energy was $3.29 \mathrm{eV}$ at $400{ }^{\circ} \mathrm{C}$. This was followed by 3.3 and $3.31 \mathrm{eV}$ at $450{ }^{\circ} \mathrm{C}$ and $500{ }^{\circ} \mathrm{C}$ respectively. An increment of $0.02 \mathrm{eV}$ in the optical band gap was obtained from 0 to $20 \% \mathrm{Na}$ content in $\mathrm{ZnO}$ thin film. This evidently shows that the band gap of $\mathrm{ZnO}$ thin film can be altered. Approximately, the band gap alteration of $\mathrm{ZnO}: \mathrm{Na}$ thin film can be deduced from Fig. 6. Here, it evidently shows that changes in the band gap are in parallel with the $\mathrm{Na}$ concentration in the thin film at $400,450,500{ }^{\circ} \mathrm{C}$ respectively.
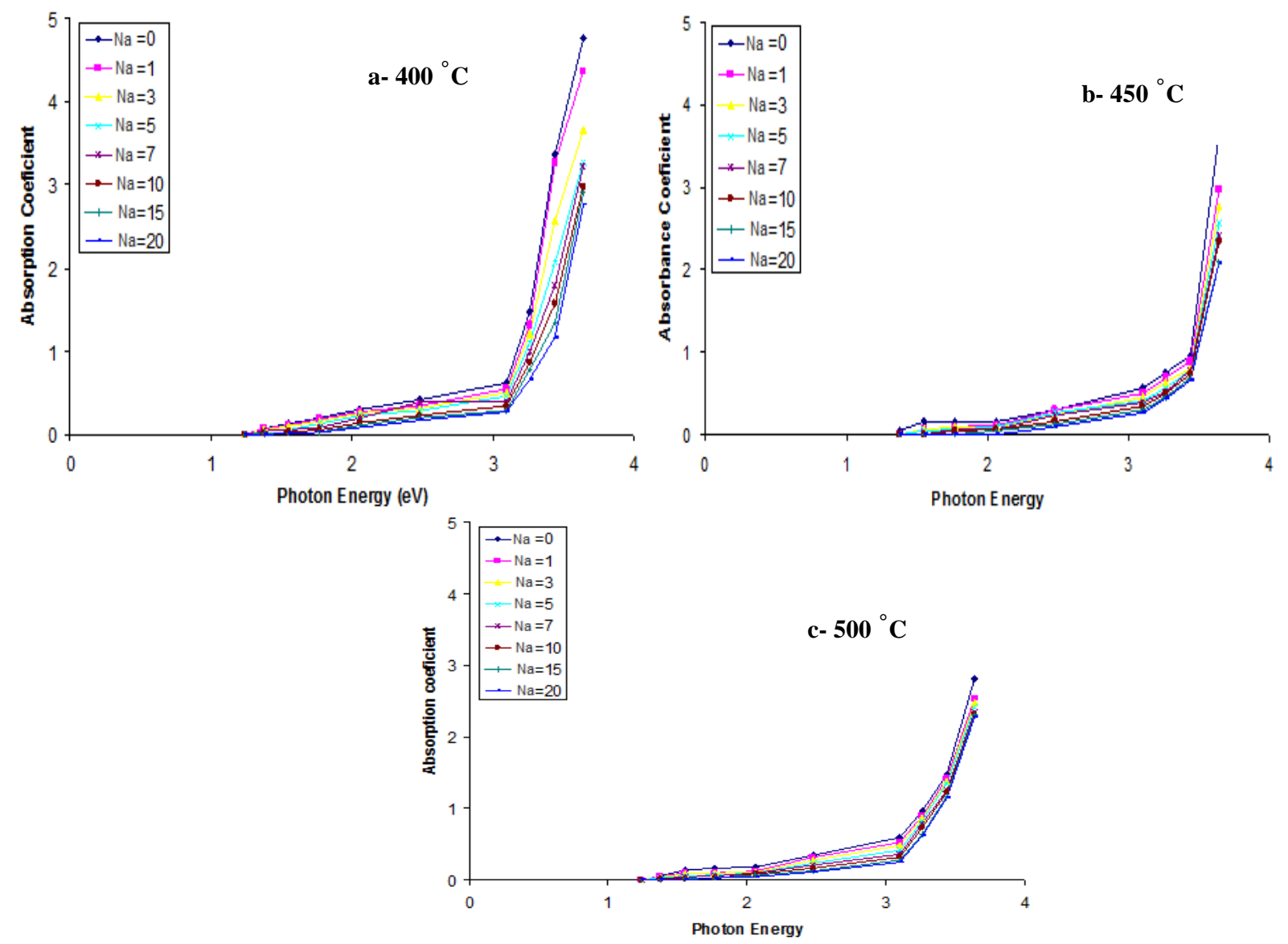

Fig. 5: Absorption coefficient vs. photon energy of representative thin films $(0,1,3,5,7,10,15,20$ of Na) at a-400, b-450, c-500 ${ }^{\circ} \mathrm{C}$.

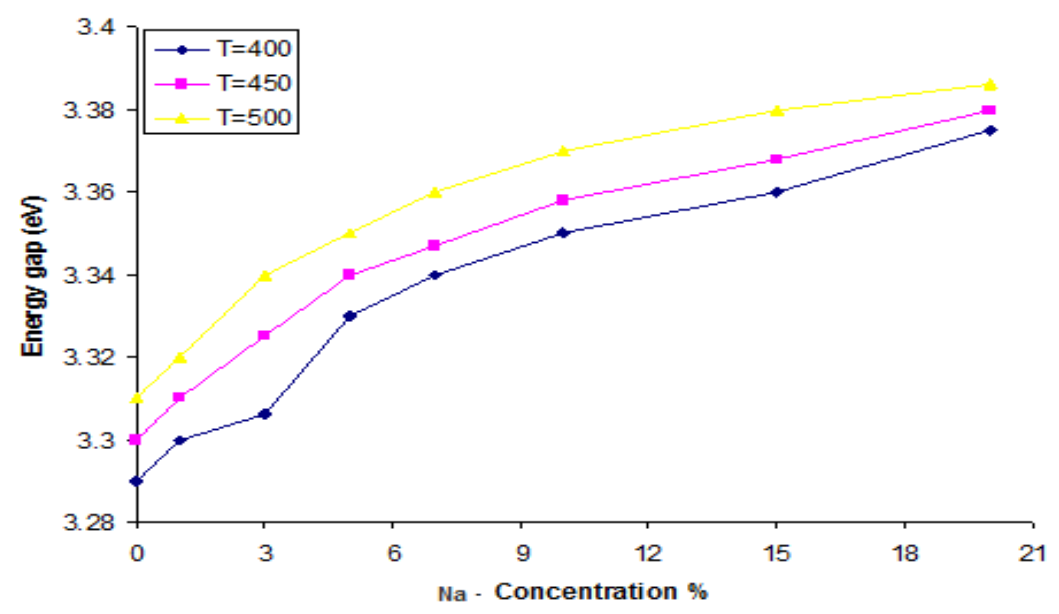

Fig. 6: Variation of energy gap with Na concentration at 400,450 and $500{ }^{\circ} \mathrm{C}$. 


\section{CONCLUSION}

In summary, pure and $\mathrm{Na}$ doped $\mathrm{ZnO}$ thin films were successfully synthesized by $\mathrm{CVD}$ technique at different substrate temperatures. The influences of substrate temperature and doping on the structural and optical properties of the samples are studied. XRD measurements indicate that the synthesized $\mathrm{ZnO}$ and $\mathrm{ZnO}: \mathrm{Na}$ films are in the hexagonal phase with a preferred orientation (002). SEM images show that better crystalline behavior for the films by increasing substrate temperatures and doping. EDXA analysis shows the chemical composition of pure and doped films with $20 \% \mathrm{Na}$. A direct optical band gap was found from the transmittance spectra. As the concentration of $\mathrm{Na}$ in the films and the substrate temperature increases, the band gap energy is affected.

\section{REFERENCES}

Azimirad, R.; Akhavan, O.; Moshfegh, A.Z. (2006). An Investigation on electrochromic properties of (WO3) $)_{1-\mathrm{x}}(\mathrm{Fe} 2 \mathrm{O} 3)_{\mathrm{x}}$ thin films. Thin Solid Films, 515(2), 644-647.

Briscoe, J.; Gallardo, D. E.; Dunn, S. (2009). In situ antimony doping of solution-grown ZnO nanorods. J. Chem. Commun., 10, 5-1273.

Chen, Y.F.; Bagnall, D.M.; Hang-junKoh; Ki-tae Park; Kenji Hirage; Ziqiang Zhu; Takafumi Yao (1998). Plasma assisted molecular beam epitaxy of $\mathrm{ZnO}$ on c- plane sapphire: Growth and characterization. J. Appl. Phys., 84, 3912.

Chen, H.X.; Ding, J.J.; Ma, S.Y. (2010). Structural and optical properties of ZnO:Mg thin films grown under different oxygen partial pressures. Physica E, 42, 1487-1491.

DeVoe, D.L. (2001). Piezoelectric thin film micromechanical beam resonators. Sensors Actuators, A 88, 263-272.

Frank McClune, W. (1976). "Powder Diffraction File".Search Manual printed in U.S.A.

Henley, S.J.; Ashfold, M.N.R.; Cherns, D. (2004). The growth of transparent conducting ZnO films by pulsed laser ablation. Surface and Coatings Technology, 177-178, 271-276.

Karthikeyan, B.; SuchandSandeep, C.S.; Pandiyarajan, T.; Venkatesan, P.; Philip, R. (2009). Optical and nonlinear absorption properties of $\mathrm{Na}$ doped $\mathrm{ZnO}$ nano particle dispersions. Applied Physics Letters, 95, 023118.

Lee, J.; Lee, D.; Lim, D.; Yang, K. (2007). Structural, electrical and optical properties of ZnO:Al films deposited on flexible organic substrates for solar cell applications. Thin Solid Films, 515, 6094-6098.

Lee, S.S.; Ried, R.P.; White, R.M. (1996). Piezoelectric cantilever microphone and microspeaker. $J$. of Micro electromechanical Systems, 5, 238-242.

Ma, T.Y.; Lee, S.C. (2000). Effects of aluminum content and substrate temperature on the structural and electrical properties of aluminum-doped $\mathrm{ZnO}$ films prepared by ultrasonic spray pyrolysis. J. Mater. Sci. Mater. Electron., 11, Issue 4, 305-309.

Mariappan, R.; Ponnuswamy, V.; Suresh, R.; Suresh, P.; Chandra Bose, A.; Ragavendar, M. (2014). Role of substrate temperature on the properties of Na-doped $\mathrm{ZnO}$ thin film nanorods and performance of ammonia gas sensors using nebulizer spray pyrolysis technique. J. Alloys and Compounds, 582, 387-391.

Mohsen, G.V.; Hamid, R.F.; Mehdi, Z. (2012). Effect of heat treatment on characteristics of nanocrystalline $\mathrm{ZnO}$ films by electron beam evaporation. J. Vacuum, 86(7), 871-875.

Purica, M.; Budianu, E.; Rusu, E.; Danila, M.; Gavrila, R. (2002). Optical and structural investigation of $\mathrm{ZnO}$ thin films prepared by chemical vapor deposition (CVD). Thin Solid Films, 403-404, 485-488.

Song, D.; Per Widenborg; Winston Chin (2002). Investigation of lateral parameter variations of Aldoped zinc oxide films prepared on glass substrates by rf magnetron sputtering. J. Sol. Energy Mater. Sol. Cells,73, Issue 1, 1-20. 
Sun, J.C.; Liang Hong-Wei.; Zhao Jian-Ze; Feng Qiu-Ju; Bian Ji-Ming; Zhao Zi-Wen.; Zhang H.; Luo, Y.; Hu, L.; Du Guo-Tong (2008). Annealing effects on electrical and optical properties of $\mathrm{ZnO}$ films deposited on GaAs by metal organice chemical vapor deposition. J. Appl. Surf. Sci., 254(22), 7482-7485.

Tsukazaki, A.; Ohtomo, A.; Onuma, T.; Ohtani, M.; Makino, T.; Sumiya, M.; Ohtani, K.; Chichibu, S.F.; Fuke, S.; Segawa, Y.; Ohno, H.; Koinuma, H.; Kawasaki, M. (2005). Repeated temperature modulation epitaxy for p-type doping and light-emitting diode based on $\mathrm{ZnO}$. Nature Materials, 4, 42-46.

Wang, D.Y.; Gao, S.X.; (2009). Influence of Annealing Condition on the Structure and Optical Properties of Na-doped ZnO Thin Films Prepared by Sol-Gel Method. J. Alloys and Compounds, 476, 925-928.

Zhao, Zi-Wen; Hu, Li-Zhong; Zhang, He-Qiu; Sun, Jing-Chang; BianJi-Ming; Liang Hong-Wei; Huo, Bing-Zhi; Yu, Dong-Qi; Chen, Xi; Fu Qiang (2009). Effect of Different Substrate Temperature on Phosphorus-Doped ZnO Thin Films Prepared by PLD on Sapphire Substrates. J. Chin. Phys. Lett., 26, 057305. 